\title{
Life Experience Method of Application Writing under the Internet+ Field
}

\author{
Li Wang \\ College of Journalism and Communications, China West Normal University, Nanchong, China \\ Email: cwnuwangli@163.com.com.cn
}

How to cite this paper: Wang, L. (2016) Life Experience Method of Application Writing under the Internet+ Field. Journal of Computer and Communications, 4, 80-88. http://dx.doi.org/10.4236/jcc.2016.414006

Received: October 27, 2016

Accepted: November 22, 2016

Published: November 25, 2016

Copyright $\odot 2016$ by author and Scientific Research Publishing Inc. This work is licensed under the Creative Commons Attribution International License (CC BY 4.0).

http://creativecommons.org/licenses/by/4.0/

\begin{abstract}
Network virtual social life and social life of the intimate contact, gaining experience through the network are growing acceptance of a new kind of practice writing behavior. In this paper, closely related to the new direction of life experience of the Internet age forms, and characteristics of practical writing life experience development under the network environment and study of teaching strategy analysis, think the Internet+ provided by the social forms life mirror, fits the practical writing "material needs" obtaining through the network to the indirect way to gain life experience of social forms, and has become a new kind of practical writing teaching methods. Network life experience is not only a practical writing, and also will use literature writing, news writing, such as writing behavior.
\end{abstract}

\section{Keywords}

Network Transmission, Virtual and Real, Life Experience, Teaching and Learning, Effects and Countermeasures

\section{Introduction}

The rapid development of Internet greatly expands the applied writing horizons. The Internet has become a network era as a new way of life of people, and directly led to the life experience of the formation of new channels, and also expanded the applied writing life source material, giving full play to the advantages of Internet+ way to strengthen practical writing network life experience and research, to ensure that network approach of the writing life material is timely and effective, because improving the quality of practical teaching plays an important role. The Internet+ is prompting practical writing teaching to carry on the profound and comprehensive transformation and upgrading. Online virtual society's prosperity and its close relation with social reality, open, equal and interactive features such as network utility in practical writing, triggered the appli- 
cation of the change of the mode of writing way and the life experience. Ubiquitous, loose, personalized learning environment, in promoting social practical writing information propagation speed at the same time, also changes the way of practical writing life source material. Practical writing life experience of the Internet era, the ways and means is showing online and offline, and virtual reality.

\section{Under the Internet+ in the Development Trend of Practical Writing Life Experience}

\subsection{With Audio and Video Watching Video Data from the Experience of Real Life}

The reality of modern network technology can make the carrying life record audio and video permanently stored on the Internet, for people to watch, download and play again and again. These data recorded a lot of action and real life, are the real life enrichment, selected after concentration. View the data, "in cyberspace to carry out related to the realistic production and life activities and information exchange and communication [1]". People can once again and set up a new real life experiences Bridges, extending tentacles of life experience of practical writing. Displays in: first of all, it is to known repeat playback of events, deepen practical writing life experience. To repeat playback watch online audio and video data, help people further careful and meticulous details of event scene and processes, analyzing the practical writing in the process of gain and loss. Especially those in real life cannot seeking in life events, audio and video playback of video, to make the life not to copy yesterday and "real" now our eyes again, create a new experience, once again in the experience of fresh overlapping, trigger a reflection on the experience, which can make up for the lack of real life experience. The second is the unknown events of the "real" experience, increased in the order of life experience. The world so big, can't experience. Ing and types of life forms are too much, not the experience, the application of the writers cannot by force of one has, for each place, eye view you see every event, experience timely reflection. Network developed for added a clairvoyant clairaudient and pair of practical writing, with the help of the new "eyes" and "ears", people can instantly without being limited by the space and time to see recently all over the world of the facts, hear echo the course of human history, the number of improving practical writing life experience. The third is to experience can speed up and promote cognitive constantly updated. Changing development of the society, the practical writing's perception of life need to continue to update and perfect. The development of the Internet is to promote the fast transmission of information and information, and to accelerate the process of the human experience of the world and speed, and further consolidate and improve the experience of cognition. Experience can speed up and the re-recognition of events, make people more comprehensive and objective analysis to absorb the experience of others, to reflect on their own experience, their experience of life in the context of a more macro to construct cognitive, in a more specific micro to parse the cognition, the further updates in the process of cognition and experience. 


\subsection{Writing Paradigm Was Used to Analyze the Implementation Skills Knowledge Construction}

The application of the era of Internet+ writing change the ways of life experience will greatly promote should with practical examples for reference. With the writing knowledge system construction and the cultivation of the writing skills, displays in: first of all, it is the vast network resources, reference laid the material foundation for the application writing. The Internet has become a way of life of people, people, based on the needs of the convenient and quick, more willing to choose closer to daily life way, experience through the network to accept applications from a writing knowledge. In online learning education mode, directly select teacher to practical writing knowledge learning, feeling experience for guidance by the teacher education; In the form of web search, online roaming access context under the condition of different examples of applied writing style, obtained by different life experiences; To download playback way to savor the analytical writing template and the details of the background, on analyzing the knowledge gain and loss, on the basis of reflection on their own knowledge. Two examples are available, makes the reference system and the mode of practical writing practice change. Simple operation, through the network can obtain many practical writing paradigms and the paradigm of template, this study results see rice chaff blowing, make people act of writing ideas have changed. To get online writing paradigm as the success of the application of writing practice standards become a kind of choices and habits, using the template as a writing paradigm on the network writing operations reference become behavior of choice, thus causing to the traditional channel (paper documents, classroom) for writing paradigm, the standard of alienation. The third is the popularity of paradigm template and use, to the construction point of knowledge and skills of practical writing. Template, a large number of practical writing paradigms on the network provides the writer with numerous sample with "Miao Gong" effect of practical writing, guide people to take to complete the writing, and the resulting scattered punctiform practical writing knowledge construction, to replace the emergency for practical writing knowledge and skills of system study.

\subsection{Complete Life Experience through Interactive Information Exchange}

In the form of interactive communication the feeling of the life experience and comprehension, the exchange of information, is a kind of life is the sublimation of life experience cognitive network, it is the age of the Internet application writing behavior of one of the most common form of expression. Displays in: first of all, it is the interaction with the exchange of timely, targeted to solve the lack of life experience. Network interaction due to the lack of life experience to solve and no pen writing problems, provides a convenient way and method. According to specific writing practice problem and timely launch network interactive experience, can be targeted to understand of life experience and knowledge of applied writing paradigm, get specific detail processing skills and writing skills. This is based on open, equality and interaction in the process of 
information communication, can be targeted to solve the problem of the lack of life experience, practical writing matters smoothly push related events. The second, in the interaction of regular information exchange process implementation understanding of experience. Network era, the communication distance is not affect writing life experience and problem. In different regions, different positions of people have different knowledge structure and thinking mode, applied writing obtain the practical writing's life experience and the source of material also is not the same. Online interaction, let more people to their comments in the process of communication, writing experience of feelings, life experience and the resulting new application writing new topic, a new round of interaction, and lead to more people involved, in the process of our life experience the snowball effect of spark new experiences, and realize the sublimation of life experience to know. The third, in the process of interaction, realize the life experience to push again. Interaction is a process of information exchange, is also a process of influencing others. Will pretreat the life experience of information through Internet transmission quickly through the interface to each other, realize the interaction between both sides of the multi-level life experience requirements, in the interactive communication in the process of life experience, let the other side (user) for practical writing and choose the needed information (such as reports, presentations, notify the application practice of writing), in the process of mutual understanding to the theory of practical writing education, the use of the Internet, mobile Internet, cloud computing, big data, such as a new generation of information technology, interactive platform as the core, with "practical, practical and pragmatic" as the entry mode, in the practical writing information release site, home page, site, interactive platform for writing life material (promote) of high frequency push, promoted the application of writing experience, knowledge dissemination, example, teaching wisdom, opens the application writing network information dissemination, information exchange, exchange the new path of results.

\section{Practical Writing Life Experience Teaching Strategy under the Network Environment}

The Internet+ is to create traditional industry new development forms [2]. New development forms, practical writing should be completed by the form of the Internet+ life experience the teaching way transformation and upgrading. Make the knowledge of life experience in the practical writing teaching organization, learning style, the mode of resource use, construct a web-based information interaction and online services support, can find practical writing material information in a timely manner, autonomy is stronger, more conducive to the writing ability of improving life experience and writing teaching practice platform.

\subsection{Build Web Applications Writing Life Experience Repository}

Fully effective management and use of all kinds of practical writing information resources, is the premise of effectively promoting practical writing teaching, scientific re- 
search, it is also an important technical means to organize the implementation of teaching. Practical writing teaching should supplement the life experience of the construction of the repository, with powerful measures to strengthen the construction of practical writing resource network times. First of all, establish the philosophy of life experience of the construction of the repository. Practical writing should be clearly established to "writing" to the repository service life experience and teaching service concept, closely related to the details of life, and with a good network education space, continuously explore new development model of teaching. In the direct experience of social life because of the time, energy, environment, such as money, position under the condition of limited conditions, pay attention to the indirect approach is to increase the life experience of knowledge teaching, broad experience requirements will be in the past, into a specific life experience knowledge, building up based on network under the condition of application writing life experience repository. From the viewpoint of the network life experience of the establishment of a repository, in the context of network diversity gain life experience, make the repository on the type, quantity, show the integral requirements of practical writing life experience, and can meet the demand of subdivided population life experience of writing. The second is to establish diversified demand of life experience repository. Practical writing must according to the demand characteristics of The Times, constantly improve the network life experience repository, specifications according to different style application, writing, writing techniques, workplace context, position forms, writing permissions, writing style and statement USES application writing practice, accurate choose corresponding types of life experience and example, enrich the content of the repository, and timely in the process of practical application of optimized stock sample, continuously strengthen the increment to add a new paradigm, in a targeted (movement, sound, like, paintings, and figure both) life experience knowledge repository configuration, promote new development of the network life experience teaching of practical writing. The third it is to open life experience database access. Resources can only be revealed in the process of using its value. To give full play to the role of life experience repository in practical writing practice, realize resources sharing. Let go of the repository access, in an open access platform, timely and effectively people need network life experience for web services support. In the process of sharing resources, relying on experience repository support, dissolve the life experience existing in the teaching of existing resources and the available resources stray not easily obtain the contradiction. Informatization level and ability to obtain, by raising the life experience and injected new energy science and technology, to the applied writing operations to solve the difficulty experience directly involved in the social life.

\subsection{Write to Adapt to the Age of the Internet Writing Textbooks}

The development of the Internet, has given rise to online life experience a new practical writing experience new mode of life, it is both to the traditional channels of practical writing life experience is rich, is also of practical writing about life experience channels 
and the discard of the material for writing. Practical writing teaching materials must adapt to the development requirements of the Internet+, realize the knowledge system of the new building. First of all, it is the network life experience knowledge into writing knowledge system construction. Practical writing teaching material knowledge system construction embodies the application of writing skills training goal and direction. Textbooks (writing, practical writing, news writing), although there are mentioned for life experience, but most of content is too broad, and theory teaching more than practical guidance. Contact with realistic social issues for network life experience, for the most part no as a kind of knowledge in the teaching material system in this paper. In fact, when the network life experience has become a practical writing skills and knowledge to strengthen the a new means of ascension itself already have the attributes of knowledge, the characteristic of this kind of knowledge, teaching methods and use skills should be attention to in the process of building teaching material system of knowledge, and to the appropriate length. The second is to strengthen the research of network life experience practice. Through the network has become an indispensable practical writing life experience for content. Manifestation of life experience, strengthen the network behavior phenomenon and the study of the patterns of experience, "helps to form education wisdom, help to tactfully education teaching action" [3]. Analysis of life experience of the original materials collection method, element of the practical writing is injected into the network life experience activity (online writing, life live view, interactive, watch writing audio-visual video, etc.), to provide users with contains elements of applied writing network source of life experience, help to make the experience in the scene, artistic conception, in communication, with the help of imagination perceptual connotation of practical writing, in feeling, validation and application, the process of practice, master the practical writing knowledge and skills. The third, it is to teach life experience method and emphasis on spot. Context, different times, forms, position of life scene (text or audio-visual materials), give a person with different experience emotions. The source of the life experience of network, the good and evil people mixed up the information on the net that is not the same, easy to interference and influence people's cognitive experience. Methods in teaching network, therefore, life experience and at the same time, "to all sorts of data and information collected from the Internet, must be careful screening, can be used as a writing material" [4]. At the same time should also be the network environment, life experience and the realistic social life with traditional life experience of interaction, the discovery of knowledge and to solve practical problems in the process of sublimation cognition to the experience, network life experience in the practical application value and significance of the practical writing.

\subsection{Use Teaching Method with the Characteristic of Network Era}

In the internet-based intelligent teaching environment, the curriculum is online [5]. In the life experience of teaching is based on Internet network. Life experiences, therefore, to carry out network teaching should highlight the characteristics of network, based on the computer and the Internet, make the use of special teaching me- 
thods of the rich network become a habit, and character. First of all, Extend network life experience of teaching resources, strengthen the construction of curriculum content. Should make full use of modern education technology, diversified, multi-channel access to the network life experience of teaching resources, as more network resources used in the practical writing course construction of life. Vigorously promote the network teaching resources sharing life experience, and promote the high-quality teaching resources of the network life experience equilibrium configuration, promote the balanced development of the practical writing teaching quality with the characteristic of the network. The second, it is to intensify the building of teaching website, enrich the network life experience material basis. To further strengthen represented by high quality courses, practical writing teaching building of web page. Will course paper text content (the teaching material content, course features, course design, teaching methods and means, the development of knowledge teaching plans, etc.) to put on the Internet, in the form of electronic text appears in the form of audio and video teacher lectures and real answer (context, voice like appearance, executive deportment, etc.), materials can reflect social life experience (audio and video, calligraphy and painting, text and video) appeared on the web page synchronization, to facilitate practical writing teaching information acquisition, analysis, use and communication, make video communication, network multimedia courseware, interactive chat and E-mail and other online tools on the life experience of teaching role play with sufficient material basis. Thirdly, it is to reform the teaching organization mode, strengthen the network life practice experience. Life experience is not only a cognitive approach, but also writing knowledge learning and skills training of a kind of teaching strategies and patterns. Practical writing teaching to adapt to the business development needs, let the network life experience practice in the classroom, carried out based on the Internet network life experience of teaching. Application writing teaching should adapt to the development of the field, which is, to add cyber life experience practice in the curriculum and perform the internet-based so called cyber life experience teaching, in order to turn the teaching class into web teaching and partical knowledge teaching into entire knowledge teaching [6]. To set the life experience of teaching tasks, with rich experience of online life material to enrich, let the classroom is not only a watch, learning and imitating model, template, more to become the first network life experience in the workplace, all in a place for the teaching implementation of classroom teaching and practice teaching goals. In interest to mobilize and inspire life experience and at the same time, strengthen the instruction of practical writing knowledge and writing skills training.

\section{Conclusions}

The realistic situation of practical writing network life experience of the application writing life experience with the characteristic of Internet new teaching way, thus promotes the progress and the development of the discipline construction practical writing practice. 


\subsection{Network Life Experience Is a Kind of Novel Practical Writing Teaching Form Rich in Content}

Along with the rapid popularization and development of the network, the network life experience both in content and form is accepted and approved for practical writing teaching. The diverse and multi-channel cyber life experience has overwhelming value in the practical application writing. It has advantage that is related to wider areas and benefits more people, which none of other methodology can surpass it. Network life experience for people to obtain material makes up for a lack of real life experience and solves the problems in writing at the same time, and also becomes one of the Internet age writing ways of life. In real social life experience and on the basis of experience, life experience made network built solid gain life experience advantages of long. To repeat, multiple life replays, contribute to improve and perfect the cognition, enrich and expand the use of the network life experience boundaries, become practical writing, and literature writing news writing for writing material cannot be ignored as an important way of life.

\subsection{Network Life Experience Will Be an Important Part of the Network Era Writing}

Needs in the life experience in the process of collecting the writing life material, are the basic premise of writing operations. The network society shows interactive teaching experience like character interaction, virtual teaching community and so on. It leads the teaching process intelligent and easy-use [7]. Practical writing teaching can't live depending on the era of network resources for nothing, still with inertia wedded to the realistic social life of themselves, and shall, in the practical life practice experience at the same time, strengthen the network life experience of research and practical use, in a new big writing ideas and perspectives to accept online life experience to join the big family, give full play to the role of the network life experience, meet the demand of the age of the Internet public application writing diversified and multi-level.

\subsection{Community Should Strengthen the Network Life Experience Resources Construction and the Spread of Voice}

Network resource building of life is the life experience implementation conditions. Weakening the spread of the life experience of network resources collection, is to ignore the practical writing's life experience, and will spread to other network resource disseminator of life experience and provide intervention conditions, causing confusion in the application of writing knowledge. Academic circle should make full use of modern education technology, actively constructing diversified, multi-level and all-round experience repository, intensify the network transmission, as much as possible to grasp the spread of the network era writing life repository building and voice. The masses in the choice and use of resources in the process of writing life experience and experience spread from authoritative sources writing life experience for the benefits of the source, to see the great value of practical writing there. 


\section{References}

[1] Wang, Q.H. (2015) The Discipline of Network Society: To Seek the Balance of Public Order and the Individuality Experience. The Theory of Journal, 10, 69-74.

http://www.cnki.net/KCMS/detail/detail.aspx?QueryID=0\&CurRec=1\&recid=\&filename $=\mathrm{L}$ $\underline{\text { LSJ201510011\&dbname }=\text { CJFDLAST2015\&dbcode }=\text { CJFQ\&pr }=\text { \&urlid }=\& y x=\& u i d=W E E v R}$ EcwSlJHSldRa1FhdkJkdjAzb2FpWDk0L05zSIZZNTNUanA5TEhlRT0=\$9A4hF_YAuvQ5o bgVAqNKPCYcEj-

KensW4ggI8Fm4gTkoUKaID8j8gFw!!\&v=MTA1NjVMRzRIOVROcjQ5RVpZUjhlWDFM dXhZUzdEaDFUM3FUcldNMUZyQ1VSTH1lWnVSdkZ5M21VNzNBS1NIWVo

[2] Chen, L. and Lin, S.Y. (2016) The Internet+ Era of Chinese Distance Education Opportunities and Challenges. Modern Distance Education Institutes, 1, 3-4.

http://www.cnki.net/KCMS/detail/detail.aspx?QueryID=4\&CurRec=1\&recid=\&filename=X DYC201601002\&dbname $=$ CJFDLAST2016\&dbcode $=$ CJFQ\&pr $=\& u r l i d=\& y x=\& u i d=$ WEEv REcwSlJHSldRa1FhdkJkdjAzb2FpWDk0L05zSIZZNTNUanA5TEhlRT0=\$9A4hF_YAuvQ5 obgVAqNKPCYcEj-

KensW4ggI8Fm4gTkoUKaID8j8gFw!!\&v=MTcwMjBGckNVUkx5ZVp1UnZGeTNtVnIzTl BTblNiYkc0SDlmTXJvOUZab1I4ZVgxTHV4WVM3RGgxVDNxVHJXTTE

[3] Yang, H. (2007) Life Experience Research Way. Science and Technology Information, 31, 142-145.

http://www.cnki.net/KCMS/detail/detail.aspx?QueryID=8\&CurRec=1\&recid=\&filename=K $\underline{\text { JXI200731098\&dbname }=\text { CJFD2007\&dbcode }=\text { CJFQ \&pr }=\& u r l i d=\& y x=\& u i d=W E E v R E c w S 1}$ JHSldRa1FhdkJkdjAzb2FpWDk0L05zSIZZNTNUanA5TEhlRT0=\$9A4hF_YAuvQ5obgVA qNKPCYcEj-

KensW4ggI8Fm4gTkoUKaID8j8gFw!!\&v=MTA3NjNMdXhZUzdEaDFUM3FUcldNMUZy Q1VSTHllWnVSdkZ5M21WNzNBTGlmVFo3RzRIdGJQcm85TWJJUjhlWDE

[4] Wang, L. (2006) Shallow Theory of Screening Writing Data and Information on the Internet. Writing.

[5] Chen, Y.M. (2016) The Internet+ Age Teaching Environment and Teaching Research. Journal of Southwest Normal University, 3, 228-232.

http://www.cnki.net/KCMS/detail/detail.aspx?QueryID=12\&CurRec=1\&recid=\&filename= $\underline{\text { XNZK201603041\&dbname }=\text { CJFDLAST2016\&dbcode }=\text { CJFQ \&pr }=\& u r l i d=\& y x=\& u i d=W E E}$ vREcwSlJHSldRa1FhdkJkdjAzb2FpWDk0L05zSIZZNTNUanA5TEhlRT0=\$9A4hF_YAuvQ 5obgVAqNKPCYcEjKensW4ggI8Fm4gTkoUKaID8j8gFw!!\&v=MDU5NDJQUlpiRzRIOW ZNckk5QlpZUjhlWDFMdXhZUzdEaDFUM3FUcldNMUZyQ1VSTHllWnVSdkZ5M21W $\underline{\text { YnpMUFM }}$

[6] Wang, L. (2006) Theory of the New Development of the Internet's Influence on the Writing Teaching and Countermeasures. Writing.

[7] Wang, Q.F. and Cao, X. (2015) “Internet + Education" Model of Development Situation Analysis. China's Education Informationization. 
Submit or recommend next manuscript to SCIRP and we will provide best service for you:

Accepting pre-submission inquiries through Email, Facebook, LinkedIn, Twitter, etc. A wide selection of journals (inclusive of 9 subjects, more than 200 journals)

Providing 24-hour high-quality service

User-friendly online submission system

Fair and swift peer-review system

Efficient typesetting and proofreading procedure

Display of the result of downloads and visits, as well as the number of cited articles

Maximum dissemination of your research work

Submit your manuscript at: http://papersubmission.scirp.org/

Or contact jcc@scirp.org 